\title{
OPPORTUNITY COSTS OF A SPARE PARTS STORAGE - A CASE STUDY IN A CRUSHING SOY INDUSTRY
}

\author{
*Renan Lorenzi Tori, Wyrllen Everson de Souza and Roberto Ribeiro Neli \\ Federal University of Technology - Paraná
}

\section{ARTICLE INFO}

\section{Article History:}

Received $14^{\text {th }}$ February, 2021

Received in revised form $06^{\text {th }}$ March, 2021

Accepted $11^{\text {th }}$ April, 2021

Published online $30^{\text {th }}$ May, 2021

\section{Key Words:}

Opportunity cost; Storage; Fuzzy logic;

Spare parts; Accounting. \begin{abstract}
The amount of money used to purchase spare parts that are kept in storage may represent a substantial opportunity cost, therefore it could be allocated in process improvements, resulting in better efficiency and bigger profits. Then, this article, besides presenting a literature review about spare parts storage accounting, it shows that the opportunity cost might represent up to $40 \%$ of the value of the spare part.
\end{abstract}

*Corresponding author: Renan Lorenzi Tori

Copyright (C) 2021, Renan Lorenzi Tori, Wyrllen Everson de Souza and Roberto Ribeiro Neli. This is an open access article distributed under the Creative Commons Attribution License, which permits unrestricted use, distribution, and reproduction in any medium, provided the original work is properly cited.

Citation: Renan Lorenzi Tori, Wyrllen Everson de Souza and Roberto Ribeiro Neli, 2021. "Opportunity costs of a spare parts storage - a case study in a crushing soy industry", International Journal of Development Research, 11, (05), 47281-47284.

\section{INTRODUÇÃO}

With an intense globalization in the economy, the competition among products (either durables or non-durables goods) are increasing considerably, motivating the companies to improve their productivity, efficiency and quality (Biehl, 2015). One of the main sectors inside of the industries segment is the maintenance, which is responsible to maintain the reliability of the machines and this way to collaborate increasing efficiency and productivity of the company. Then, seeking this efficiency, several maintenance strategies have been utilized throughout the years. However, despite of their importance, this paper will focus on the Total Productive Maintenance (TPM). This method has as its main goal the reduction of losses related to production processes and administrative processes. In other words, it aims the continuous improvement of the processes, lowering expenses and making the product more competitive in the market (Junior, 2012). The industries that use the TPM strategy should evaluate the production costs, such as supplies, labour or equipment maintenance. To preserve the machines working in their expected productivity, spare parts are stored to ensure the minimum down-time, that is, the period when the processes are halted (Da silva, Madeira, 2004). Freitas (Freitas, 2004), on the other hand, presents another functionality for storages as production flow and sales, aiming to create independent processes in the factory, enabling each one of them to pursue higher efficiency. The management for spare parts storage, then, should be done with wisdom, considering that non- reduction in the net profit by maintenance costs caused by the lack of the parts (Freitas, 2004). In order to obtain a profitability analysis of the company about the factors that it depends on - as sales, purchases, storage and expenses - there is an area of study called financial accounting and, according to Neves and Viceconti (Viceconti, 2009), its purpose is to manage the financials of the company, aside from presenting the profits and earnings made by operation. There are, in the field of accounting, some words that should be comprehended to enhance the understanding of this article, which are: expense, direct and indirect costs. Expense, as presented by Neves and Viceconti (Viceconti, 2009), is "cession of an asset with the purpose to obtain a good or service, represented by the deliver or deal to deliver good or rights (usually money)". In this way, it is possible to say that the firm purchases, through a financial commitment, a good or service needed by the company (Rosa, 2010). Neves and Viceconti (Viceconti, 2009) categorize the expense in 3 types: investments, direct and indirect costs. The investment is "an expense with a good or service that is measured by its life cycle or from its benefits assigned to future periods". The direct cost present by Silva et. al. (2019) is essential to the company, since it embraces the transformation process of a raw material to a final product or the development of a service. It is the type of expense that is used to produce a product or a service, in other words, it is linked directly to the production. On the other hand, the indirect cost has no direct connection to the production of a good or the creation of a service. An example of this type is the amount spent with salaries of an 
administrative area of the firm. Ribeiro, (Ribeiro, 2018), in order to distinguish direct and indirect costs, define them as follows "the direct cost composes the product, it goes to storage and increases the current assets; the indirect one reduces the profit, it goes to the results and diminishes equity". There are many ways to manage the storage and their goal are to "balance the maintenance storage, acquisition and lack costs, obtaining the minimum total costs", says Rabelo (2009). These models vary according to the product that is stored, with the demand profiles from their clients, market field on which the company plays a role and others (Correia, 2016). In (Figure 1) is shown an illustration about how should be achieved this minimum cost.

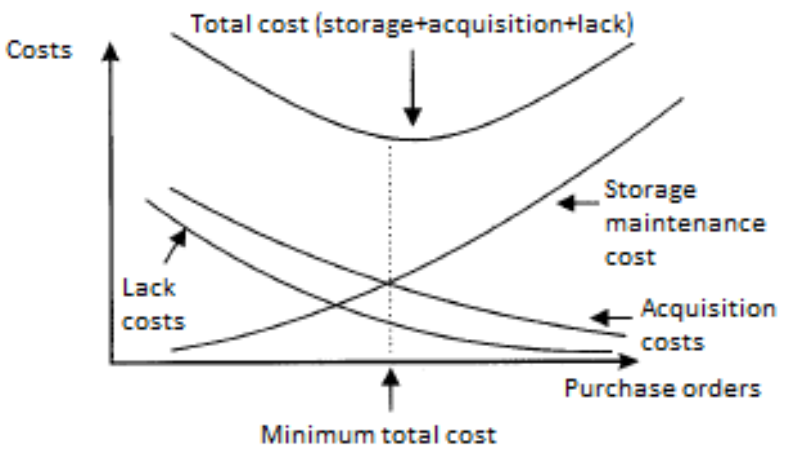

Figure 1. Costs vs. purchase orders. Made by Rabelo [9]

The figure indicates the indirect proportion played by the purchase orders and, by consequence, items bough versus the acquisition costs. In other words, when increasing the amount of purchase orders, the quantity of items will also increase and at the same time, the acquisition costs reduce it following the concept that the as bigger is the quantity purchased as lower would be the acquisition costs. Adding to that, the cost of not having a spare part (lack cost) diminishes as higher the number of parts in storage. However, as higher the quantity requested for purchases, the maintenance cost of storage becomes elevated, after all there will be more parts to be stored that should be maintained in good conditions for use. Therefore, considering the complexity of management of a warehouse, it has been performed a research regarding spare parts storage related to electrical, electronics and instrumentation in a crushing soy industry located in Campo Mourão, interior of state of Paraná, Brazil. In addition to that, with the acquired data, it will be shown the opportunity cost of some items in order to demonstrate optimization idea regarding the management of the spare parts storage.

\section{MATERIAL AND METHODS}

Material: The electronics maintenance department of the soy crushing industry holds a spreadsheet containing all spare parts that have been bought in order to follow up and keep track of the entire processes, since its purchase until the delivery, ensuring that it arrives within the specified deadline (usually determined by the buyer). This data (Error! Reference source not found.) has purchases orders since 2017 and, currently, it embraces more 1600 items. So, through this document, it is possible to verify the inventory turnover. With this spreadsheet shown on (Error! Reference source not found.), it is possible to detect the items that had a high or low inventory turnover. It was defined a criterion that only spare parts that had been purchased more than 3 times were included in the (Error! Reference source not found.). On the first column (called CPD), it is displayed the code that identifies every item inside the company's storage system.

Methods: Aiming to optimize the management of the storage in this industry, the given study has been classified as applied with an exploratory and quantity approach (Gil, 2011). This article is a study case developed in a crushing soy industry, on which the data was obtained in the electronics maintenance department and shown on (Error! Reference source not found.). Below is described some of the variables of the (Error! Reference source not found.).

- Storage items: it is the amount that was received and made available in the storage on the last delivery.

- Average/unit: this value, shown in Reais (R\$), is given by ERP System (Enterprise Resource Planning) considering the average price that was purchased this item per unit.

- Total value storage: it is the amount, in Reais (R\$), expressed by the quantity in storage multiplied by its price average of each spare part.

- Inventory turnover per unit: given in days, is calculated by the difference between the last two deliveries of this item, divided by the quantity of items. This way, the value displayed is the number of days that is necessary to consume an unit of the item. It is important to mention that the period between the purchase order until the delivery it is not being considered in the calculation.

Future storage value: the amount shown on this column, in Reais $(\mathrm{R} \$)$, is calculated by Future value $=$ Present $_{\text {value }}(1+i)^{n}$, where $n$ represents the inventory turnover per unit and $i$ is the interest rate that is obtained financial resources, in another words, the opportunity rate. For this example, was considered $i=2,25 \%$ per year or $0,074 \%$ per day, which is the Selic rate, that is controlled by Central Bank of Brazil. Besides that, the variation of $n$ has not been considered. In the cases that the quantity stored was bigger than 5 units, it has been separated the calculus of the future value of each item, in other words, the present value was diminished by 1 for each $n$, ensuring, in this way, the error margin has been diminished considerably. For instance, a spare part that has 10 units in the storage, will be calculated by:

$$
\begin{gathered}
F_{V}=P_{V} * 10(1+i)^{n * 10}+P_{V} * 9(1+i)^{n * 9}+P_{V} * 8(1+i)^{n * 8} \\
+\cdots+P_{V}(1+i)^{n}
\end{gathered}
$$

Below it is shown how it is obtained the future value of the CPD (initials for the code for each item in storage) 991228:

$$
\begin{aligned}
& F_{V}=P_{V}(1+i)^{n} \\
& F_{V}=4063,57 * 2 *(1+0,074 \%)^{167,5 * 2} \\
& F_{V}=8127,14(1,00074)^{335} \\
& F_{V}=8127,14(1,281214238)=10412,61
\end{aligned}
$$

Opportunity cost: it is the difference, in Reais (R\$), between total value and the future value.

With (Error! Reference source not found.), it is possible to check the influence for each CPD between total value storage and its future value. Then, on (Error! Reference source not found.), it is shown the relation between the future value of each CPD and its average price. It is also displayed the ratio between the opportunity cost and average price.

To explain how was obtained the data above on (Error! Reference source not found.), is used CPD 1137730 and its data on (Error! Reference source not found.).

Value $_{\text {totalstorage }}=\frac{7333,48}{105323,40}=6,96 \%$

Future $_{\text {valuestorage }}=\frac{12507,79}{133245}=9,39 \%$ 
Relation $_{\text {opportCostxavgPrice }}=1-\frac{12507,79}{7333,48}=41,37 \%$

\section{ANALYSIS OF THE RESULTS}

From the data obtained on the last chapter, it is possible to say that the opportunity cost was R\$28.000,00 (around U\$ 5.300,00),
Analysing Table 1 can be noticed that the spare parts that had a lower opportunity cost than the others are related due total amount in
47283 value writh annortunitur moct

International Journal of Development Research, Vol. 11, Issue, 05, pp. 47281-47284, May, 2021

\begin{tabular}{|c|c|c|c|c|c|c|c|c|c|c|c|c|}
\hline $\begin{array}{l}\text { equisic } \\
\text { ào }-1\end{array}$ & $\begin{array}{l}\text { Priorid } \\
\text { ad }\end{array}$ & $\begin{array}{l}\text { Tem } \\
\text { CPI }\end{array}$ & $\begin{array}{l}\text { Pedid } \\
\text { a }\end{array}$ & prog & $\begin{array}{l}\text { Data } \\
\text { repro: }\end{array}$ & $\begin{array}{c}\text { Dias } \\
\text { corrido }\end{array}$ & $\begin{array}{l}\text { Data real } \\
\text { entred }\end{array}$ & $\begin{array}{c}\text { Dias } \\
\text { atrasa:- }\end{array}$ & $\mathrm{CPE}=$ & MaterialłDescriçäo & Setol - & Status \\
\hline 314877 & Média & Sim & 356491 & $14 / 05+2020$ & & 36 & $25105+2020$ & 11 & 1219014 & JOGO DE REPARO DSECIG-50 COD. 753090 FESTO & Margarina & OKFORAPRI \\
\hline 314877 & Média & Sim & 356491 & $14105+2020$ & & 36 & 2510512020 & 11 & 1229656 & VALLULLA, REGULLADORA, DE FLUXO GRLA-318-B COD. 151178 FES & Margarina & OKFORAPRAZZI \\
\hline 314877 & Média & Sim & 356491 & $14 / 05+2020$ & & 36 & $25105+2020$ & 11 & 1298682 & JOGO DE REPARO DSBC-63 COD. 13116643 FESTO & Margarina & OKFORAPRARZI \\
\hline 314896 & Alta & Nã̃o & 356491 & $29105+2020$ & & 64 & $25105+2020$ & .4 & 1384899 & Atuador linear DGC-32-800-KF-YSR-A cod. 532448 Festo & Margarina & OK \\
\hline 314922 & Média & Não & 356461 & $14+05+2020$ & & 36 & $25+05+2020$ & 11 & 1384970 & Valu. bloq. borboleta HE-2-QS-6 cod. 153467 Festo & Margarina & OKFORAPRARZ \\
\hline 314934 & Média & Nã̃o & & & & & & & 1384996 & Rele tempo TW2124VCA cod. 11099025 Coel & Operacional & AG. APROVAÇ, \\
\hline 314936 & Alta & Não & & & & & & & 1385069 & Retificador BEG 143270V B2 1A STM do Brasil & Envase & AG. APROVAÇAi \\
\hline 314981 & Baira & Sim & 355482 & 2610422020 & & 13 & & & 1005944 & LAMPADA TL5 14W ECOH865 PHILIPS & Geral & PED. ATRASSADC \\
\hline 315794 & Média & Sim & 356873 & $18+05+2020$ & & 34 & $18+05+2020$ & 0 & 1237381 & SINALLZADODOR LED MF-LD12-24DC COD. 19143 FESTO & Margarina & OK \\
\hline 315796 & Baira & Sim & 356979 & $28105+2020$ & & 44 & $18+05+2020$ & -10 & 984787 & CONTROLA.DOR N1200 UNIVERSALL PID AUTO-ADAAPTATVONO' & Caré & OK \\
\hline 315796 & Baira & Sim & 356979 & $11105+2020$ & & 27 & $18+05+2020$ & 7 & 1003437 & CONTROLA.DOR N1100 24VCA UNIVERSA.L MARCA NOVUS (IND. & Café & OKFORAPRAZ \\
\hline 315830 & Média & Sim & 356982 & $28105+2020$ & & 44 & $20105+2020$ & -8 & 452416 & Fonte 120ł230VAC 24VDC 5A 6ES73071EA,010A.,0 Siemens & Geral & OK \\
\hline 315962 & Média & Nã̃o & & & & & & & 1387014 & Flange oscilante SNCB-40 cod. 174391 Festo & Café & AG. APROVAÇBi \\
\hline 315962 & Média & Nã̃o & & & & & & & 1387022 & Cavalete LSN-40 cod. 5562 Festo & Caré & AG. APROVAÇA \\
\hline 316125 & Média & sim & 357400 & $17706+2020$ & & 58 & & & 354481 & MOTOR WEG $40 \mathrm{CV} 3801660 \mathrm{~V} 50160 \mathrm{HZ} 3560 \mathrm{RPM}$ & Caldeira & PED ATRASSADC \\
\hline 316264 & Média & Nẵo & 356923 & $17706+2020$ & & 58 & & & 1388142 & Kit reparo SPC 050281 Norgren UW -00047 & Moinho Trigo $\mathrm{F}$ & PED. ATRASADC \\
\hline 316305 & Média & Sim & 357191 & $15+05+2020$ & & 21 & 14/05t2020 & -1 & 1314386 & THILEX LIMPADOR AR COND. GALA.OO 5 LTS QUIMILAUS $(2710.19 .1$ & Geral & $\mathrm{OK}$ \\
\hline 316344 & Baina & Sim & 356491 & $14 / 05+2020$ & & 19 & $14 / 05 / 2020$ & 0 & 941735 & FILTRO REGULA.AORILFR-114-D-MINIICOD. 159631 FESTO & Refinaria & OK \\
\hline 316345 & Alta & Sim & 356200 & $02105+2020$ & & 7 & & & 1265482 & BATERIA DE LITHIUM 3 V VERDE COD. A98-0031-0012 FANUC & Moinho Trigo F & PED. ATRASADC \\
\hline 316346 & Média & Sim & 356938 & 0710612020 & & 43 & & & 956783 & SOFTSTARTER 80A:40GRAUS 3RW/3046-1BB14 SIEMENS & Operacional $\mathrm{F}$ & PED. ATRASADC \\
\hline 316347 & Baixa & Sim & 356491 & $14105+2020$ & & 19 & $25105+2020$ & 11 & 1008250 & GARFOSG-M12*1,25 & Margarina & OKFORAAPRAZZI \\
\hline 316366 & Baina & Sim & 357435 & $18+05+2020$ & & 23 & & & 987751 & BOBINA. 2201230V 10W COD. 018F 7363 PIVA.LV.SOLEN. 018F 7367 C & = Margarina & PED. ATRASSADC \\
\hline 316488 & Média & Sim & 358074 & $10+07+2020$ & & 73 & & & 1051385 & CAIXA PI BOTAO 1FURO 22M AMARELLA M22-IY1 - EATON (IND. 1 & Geral & PED. ANDAMEI \\
\hline 316632 & Alta & Sim & 356580 & $10+05+2020$ & & 11 & $12105+2020$ & 2 & 930504 & LAMPADA COD. 133665 SIDEL $2500 \mathrm{~W} 400 \mathrm{~V} 380 \mathrm{MM}$ & Envase & OKFORAPRAZZI \\
\hline 316632 & Alta & Sim & 356580 & $10+05+2020$ & & 11 & $12+05+2020$ & 2 & 930512 & LAMPADDA COD. 133669 SIDEL $3000 \mathrm{~W} 400 \mathrm{~V} 380 \mathrm{MM}$ & Envase & OKFORAPRA \\
\hline 316633 & Baina & Sim & & & & & & & 1151045 & 16 CARTBOD|GITAL DE ENTRADA 24 VDC COD. E & 1) Margarina & \\
\hline
\end{tabular}

Figure 2. Follow-up of purchased items

Table 1. Opportunity cost of present storage

\begin{tabular}{|c|c|c|c|c|c|c|}
\hline CPD* & $\begin{array}{l}\text { Storage items } \\
\text { (unit) }\end{array}$ & $\begin{array}{c}\text { Average } \\
\text { price/unit (R\$) }\end{array}$ & $\begin{array}{c}\text { Total value } \\
\text { storage }(\mathrm{R} \$)\end{array}$ & $\begin{array}{c}\text { Inventory } \\
\text { storage/unit (days) }\end{array}$ & Future value (R\$) & $\begin{array}{c}\text { Opportunity cost } \\
\text { (RS) }\end{array}$ \\
\hline 1269569 & 10 & 64,16 & 641,60 & 10,7 & 692,23 & 50,63 \\
\hline 1269577 & 10 & 23,35 & 233,50 & 12,39 & 254,58 & 21,08 \\
\hline 991252 & 1 & $\mathrm{R} \$ \quad 973,69$ & 973,69 & 45 & $\mathrm{R} \$ \quad 1.006,65$ & 32,96 \\
\hline 1143611 & 5 & $\mathrm{R} \$ 1.576,10$ & $7.880,50$ & 10,35 & R\$ $8.188,02$ & 307,52 \\
\hline 1147730 & 11 & $\mathrm{R} \$ \quad 666,68$ & $7.333,48$ & 84,1 & R\$ $12.507,79$ & $\mathrm{R} \$ \quad 5.174,31$ \\
\hline 1050850 & 1 & $\mathrm{R} \$ 6.099,00$ & $6.099,00$ & 62 & $\mathrm{R} \$ \quad 6.385,23$ & 286,23 \\
\hline 1251236 & 2 & $\mathrm{R} \$ 2.359,83$ & $\mathrm{R} \$ \quad 4.719,66$ & 119 & $\mathrm{R} \$ \quad 5.628,21$ & 908,55 \\
\hline 1278894 & 2 & $\mathrm{R} \$ 7.239,00$ & $\mathrm{R} \$ \quad 14.478,00$ & 84,5 & R\$ $16.405,95$ & R\$ $1.927,95$ \\
\hline 1286617 & 2 & $\mathrm{R} \$ 3.786,00$ & $7.572,00$ & 151,4 & $\mathrm{R} \$ \quad 9.473,01$ & $\mathrm{R} \$ \quad 1.901,01$ \\
\hline 1251791 & 10 & $\mathrm{R} \$ 1.910,26$ & $\mathrm{R} \$ 19.102,60$ & 65,5 & R\$ $28.583,86$ & R\$ $9.481,26$ \\
\hline 1249568 & 1 & $\mathrm{R} \$ 3.855,60$ & $3.855,60$ & 154 & $\mathrm{R} \$ \quad 4.320,82$ & 465,22 \\
\hline 1215019 & 5 & $\mathrm{R} \$ \quad 554,55$ & $2.772,75$ & 40,2 & $\mathrm{R} \$ \quad 3.217,24$ & 444,49 \\
\hline 930504 & 20 & $\mathrm{R} \$ \quad 130,03$ & $2.600,60$ & 31,2 & $\mathrm{R} \$ \quad 3.810,53$ & $\mathrm{R} \$ 1.209,93$ \\
\hline 991228 & 2 & $\mathrm{R} \$ 4.063,57$ & $8.127,14$ & 167,5 & R\$ $10.412,61$ & R\$ $2.285,47$ \\
\hline 1005537 & 2 & R\$ 408,99 & 817,98 & 112,25 & 965,75 & 147,77 \\
\hline 1029835 & 15 & $\mathrm{R} \$ \quad 385,00$ & $5.775,00$ & 8 & R\$ $6.288,53$ & 513,53 \\
\hline 1062603 & 6 & $\mathrm{R} \$ 1.515,01$ & $9.090,06$ & 58 & R\$ $11.480,33$ & R\$ $2.390,27$ \\
\hline 1261550 & 1 & $\mathrm{R} \$ 1.808,74$ & R\$ $1.808,74$ & 68,5 & R\$ $1.902,75$ & 94,01 \\
\hline Total & & & RS $105.323,40$ & & R\$ $133.245,00$ & R\$ 27.921,60 \\
\hline
\end{tabular}

Table 2. Relations between average price and opportunity cost.

\begin{tabular}{|c|c|c|c|c|c|c|}
\hline CPD & $\begin{array}{l}\text { Total value in } \\
\text { storage (\%) }\end{array}$ & $\begin{array}{l}\text { Placing by } \\
\text { total value }\end{array}$ & $\begin{array}{c}\text { Future value in } \\
\text { storage }(\%)\end{array}$ & $\begin{array}{c}\text { Placing by } \\
\text { future value }\end{array}$ & $\begin{array}{l}\text { Ratio opport. cost } \\
\text { and avg. price }(\%)\end{array}$ & $\begin{array}{l}\text { Placing opport. cost } \\
\text { and avg. price }\end{array}$ \\
\hline 1251791 & $18,14 \%$ & 1 & $21,45 \%$ & 1 & $33,17 \%$ & 2 \\
\hline 1278894 & $13,75 \%$ & 2 & $12,31 \%$ & 2 & $11,75 \%$ & 11 \\
\hline 1062603 & $8,63 \%$ & 3 & $8,62 \%$ & 4 & $20,82 \%$ & 5 \\
\hline 991228 & $7,72 \%$ & 4 & $7,81 \%$ & 5 & $21,95 \%$ & 4 \\
\hline 1143611 & $7,48 \%$ & 5 & $6,15 \%$ & 7 & $3,76 \%$ & 18 \\
\hline 1286617 & $7,19 \%$ & 6 & $7,11 \%$ & 6 & $20,07 \%$ & 6 \\
\hline 1147730 & $6,96 \%$ & 7 & $9,39 \%$ & 3 & $41,37 \%$ & 1 \\
\hline 1050850 & $5,79 \%$ & 8 & $4,79 \%$ & 8 & $4,48 \%$ & 17 \\
\hline 1029835 & $5,48 \%$ & 9 & $4,72 \%$ & 9 & $8,17 \%$ & 14 \\
\hline 1251236 & $4,48 \%$ & 10 & $4,22 \%$ & 10 & $16,14 \%$ & 8 \\
\hline 1249568 & $3,66 \%$ & 11 & $3,24 \%$ & 11 & $10,77 \%$ & 12 \\
\hline 1215019 & $2,63 \%$ & 12 & $2,41 \%$ & 13 & $13,82 \%$ & 10 \\
\hline 930504 & $2,47 \%$ & 13 & $2,86 \%$ & 12 & $31,75 \%$ & 3 \\
\hline 1261550 & $1,72 \%$ & 14 & $1,43 \%$ & 14 & $4,94 \%$ & 16 \\
\hline 1008668 & $1,37 \%$ & 15 & $1,29 \%$ & 15 & $16,24 \%$ & 7 \\
\hline 1005537 & $0,78 \%$ & 17 & $0,72 \%$ & 17 & $15,30 \%$ & 9 \\
\hline 1269569 & $0,61 \%$ & 18 & $0,52 \%$ & 18 & $7,31 \%$ & 15 \\
\hline 1269577 & $0.22 \%$ & 19 & $0.19 \%$ & 19 & $8.28 \%$ & 13 \\
\hline
\end{tabular}


Dollars), value that could be used as investments to improve process efficiency. Through this article it could be shown that, for some items of author's research, the quantity in storage exceeds the real needs, increasing expenses of maintenance storage, aside from the opportunity cost.

This way, when the total value in storage is significant (above the average of $\mathrm{R} \$ 5.000,00)$, the opportunity cost might be high, mostly

where the future value is nearly $41 \%$ of the total amount in the current escrow. This means that only with this expense, it could be purchased, at least, 7 more pieces of this CPD.

Even though some items might have small average value, as the CPD 930504 (only the $13^{\circ}$ bigger value, as demonstrated in (Error!

Reference source not found.)) the future value of this spare part is nearly $32 \%$ of the present value. Thus, with this amount of opportunity cost, it is possible to buy 9 more items as this one. Hence, with a better management of the warehouse, it can be achieved a considerable saving on money, even with lower value parts. The opportunity cost of the CPD 930504 is due the quantity that was storage, which was 20 pieces, and by its inventory turnover for each item, calculated as 31 days. In another words, if this statistic had been kept, it would take 620 days or 1 year and a half to use all parts. Therefore, there is an excess of this CPD in the warehouse and it should be created a criterion to check how many pieces should be purchased. Besides that, the criterion is required, after all, if there are an excessive amount of spare parts in storage, the maintenance storage cost increases dramatically, causing more losses, as shown on Figure 1. Nowadays, one of the main reasons to buy and storage a large quantity of items is the large lead time (time between the request and delivery of the material), which is 50 days in average, with a standard deviation of 30 days. So, there are spare parts that are delivered 80 days after the request. Through Table 1, it is possible to verify that the average between the ratio of the price average and the opportunity cost is, for each item, $15,4 \%$. Then, considering that the warehouse of this branch of the company has almost 28 thousand items registered, total value of 21 million of Reais and that the opportunity cost is $15,4 \%$ for each spare part, the amount spent with this type of cost is 3,3 million of Reais, almost 558 thousand US Dollars. Even though this cost is high, when the process is not running due a lack of a spare part in storage to repair a machine the company loses almost R $\$ 1.500,00$ per hour. So, in another words, if the process is stopped for 10 hours, the losses of the company for this example are more than R\$ $15.000,00$ (equivalent to US\$ $3.000,00$ considering the current exchange rate). Despite that, in normal operational conditions the company could have more than $\mathrm{R} \$$ $75.000,00$ (around US\$ 14.000,00) in profits considering the same period. Theni, $\mathrm{n}$ order to achieve the best trade-off from the opportunity, the maintenance and the lack costs, the author propose an implementation of a system based on fuzzy logic to manage a warehouse. Thus, this system would evaluate if a spare part should be kept in storage and, if affirmative, it will provide the minimum quantity. The proposal of the author considers the criticality of an item, its cost, lead time and inventory turnover. The scope of this project will be delimited for only spare parts that are used in maintenances of machines, mainly by their high values. The project will not consider the maintenance storage cost and purchases services. Likewise, lead time will be considered constant. This system will be implemented directly on MATLAB ${ }^{\circledR}$ platform, in which will be possible to test the system proposed for management storage of the crushing soy industry.

\section{CONCLUSION}

The main goal of the article was to demonstrate, principally, an estimation of the opportunity cost that this soy crushing industry has. Therefore, this goal has been achieved, as it was pointed out that the opportunity cost is about 3 million of Reais (558 thousand US
Thus, this research can contribute to the company, enhancing its efficiency, as soon as could be developed a criterion of evaluation for purchases of spare parts. In this way, it will be possible to reduce the total spare parts that are in storage, decreasing costs. As well, as mentioned from the author, it is feasible the development of a system based in fuzzy logic to identify the needs of items in storage and its minimum quantity. Then, with the output given by the system, hopefully a comparison of the current number of parts in storage and the value given by the system can be established, in a way that either the money is being allocated in items that could be reduced or that could be cut out, enabling the possibility to purchase parts that should be constant in the storage.

\section{REFERENCES}

Biehl, N. C., \& Sellitto, M. A. (2015). Tpm and autonomous maintenance: case study in a metal mechanic company. Revista Produção Online, 15(4), 1123. doi:10.14488/16761901.v15i4.1632

Junior, A. S. M et al (2012). "Proposta de aumento de eficiência fabril por meio da manutenção produtiva total em uma empresa fabricante de embalagem de alumínio". Encontro Nacional de Engenharia de Produção, 32. Availableat http://www.abepro. org.br/biblioteca/enegep2012_TN_STO_157_917_20453.pdf

Da silva, C. B. A., Madeira, G. J. (2004). "Gestão de Estoques e Lucro da Empresa". Contabilidade Vista \& Revista, 15(2), 41. Availableat https://revistas.face.ufmg.br/index.php/ contabilidadevistaerevista/article/view/256

Freitas, R. P (2004). Inventory control of spare parts: literature review and a case study. Rio de Janeiro, Brazil: Universidade Católica do Rio de Janeiro. doi: 10.17771/PUCRio.acad.12396.

Viceconti, P., Neves, S (2009). "Contabilidade de custos". São Paulo, Brazil: Publicationof Saraiva. ISBN 9788553131273.

Rosa, F. F (2010). "A contabilidade de custos e a sua relevância para a gestão”. Porto Alegre, Brazil: Universidade Federal do Rio Grande do Sul. Available at https://lume.ufrgs.br/bitstream/ handle/10183/27218/000763037.pdf

Silva, J. D. et al (2019). "Gestão de custos como ferramenta de planejamento e controle: um estudo no jornal gazeta do oeste em Mossoró/RN". Congresso Brasileiro de Custos, 26. Availableat https://anaiscbc.emnuvens.com.br/anais/article/ view/3689

Ribeiro, O. M (2013). "Contabilidade de custos fácil”. São Paulo, Brazil: Publicationof Saraiva. ISBN 9788502202085.

Rabelo, F. C (2009). "Gestão de estoques na cadeia de logística integrada". São José dos Campos, Brazil: Universidade do Vale do Paraíba. Available at https://www.academia.edu/download/ 56289369/GESTAO_DE_ESTOQUE NA_CADEIA_DE_LOGI STICA_INTEGRADA_-_13_PGS.pdf

Correia, M. F. Z (2016). Proposal for application the fuzzy logic in surgical materials of central warehouse in hucff to assist the decision-making concerning the stock control. Rio de Janeiro, Brazil: Universidade Federal do Rio de Janeiro. Available at http://www.producao.ufrj.br/index.php/en/informacoessacademicas/teses-e-dissertacoes/mestrado/2016-1/229--198/file

Gil, A. C (2002). “Como elaborar projetos de pesquisa”. São Paulo, Brazil: Publication of Atlas. 
